\title{
THE WEAK ASPECTS OF THE INDUSTRIAL DESIGN PROTECTION SYSTEM IN INDONESIA
}

\author{
Cita Citrawinda Noerhadi ${ }^{1}$
}

\begin{abstract}
Industrial property is is being used by an increasing number of developing countries as an important tool of technological and economic development. Developing countries have also been made aware that it is in their best interest to establish national industrial property systems. Indonesia as a signatory member of the Agreement on Trade Related Aspects of Intellectual Property Rights (TRIPS) of the World Trade Organization (WTO), Indonesia has enacted Law No. 31 of 2000 concerning Industrial Design on 20 December 2000. Since the enactment of Law No. 31 of 2000 several cases have occurred and been brought before the Commercial Court involving the cancellation of lawsuits with regard to issues of the lack of 'novelty' of an industrial design which have already been granted to other people. There are several weak aspects of Law No. 31 of 2000 which in practice can create legal uncertainty and may potentially cause a barrier towards the effectiveness of the implementation of Law No. 31 of 2000.
\end{abstract}

Keywords: Industrial Property, Agreement on Trade Related Aspects of Intellectual Property Rights, Law No. 31 of 2000, Industrial Design

\section{Introduction}

Industrial property has long been recognized and used by industrialized countries, and is being used by an increasing number of developing countries, as an important tool of technological and economic development. Many developing countries are aware that it is in their best interest to establish national industrial property systems. Countries that are members of the World Trade Organization (WTO) are parties to the Agreement on Trade-Related Aspects of Intellectual Property Rights, also known as TRIPS. The TRIPS requires members of the WTO to have laws in place that provide for different kinds of IP protection. Therefore, as a signatory member of the Agreement on Trade Related Aspects of Intellectual Property Rights (TRIPS) of the World

1 Cita Citrawinda is founder and IP consultant at Law Office Cita Citrawinda Noerhadi \& Associates and a lecturer on Intellectual Property Rights and the Postgraduate Program of the Faculty of Law, Universitas Indonesia. She got her Bachelor of Law (Sarjana Hukum) from Universitas Indonesia (1985), Master in Intellectual Property (MIP) from Franklin Pierce Law Center, Concord, New Hampshire, USA (1993), and Doctor of Laws from Universitas Indonesia (1999) with the predicate of cum laude. 
Trade Organization (WTO), ${ }^{2}$ Indonesia enacted laws and regulations in Intellectual Property Rights; among others, Law No. 31 of 2000 concerning Industrial Design on December 20, 2000.

The Industrial Design Law adopts a constitutive system, that is, to obtain industrial design protection, the industrial design must be registered at the Directorate General of Intellectual Property, Ministry of Law and Human Rights of the Republic of Indonesia. According to Article 1 para. (1) of Law No. 31 of 2000 concerning Industrial Design, Industrial Design shall mean a creation in the shape, configuration, or the composition of lines or colors, or lines and colors, or the combination thereof, in a three or two dimensional form which gives aesthetic impression and can be realized in a three or two dimensional pattern and used to produce a product, goods, industrial commodity or a handy craft.

The right to industrial design shall mean an exclusive right granted by the State of the Republic of Indonesia to a Designer ${ }^{3}$ for his creation for a certain period of time to exploit his creation by himself or to give permission to another party to make, use, sell, import, export and/or distribute the products that have been granted the right to the industrial design. ${ }^{4}$ The right to industrial design shall be granted for an industrial design that is new.

Exempted from the above provision is where the use of the industrial design is for the purposes of experimentation and education, provided that such use does not damage the normal interest of the rights holder to the industrial design. ${ }^{5}$ The right to industrial design shall not be granted if an industrial design is contrary to the prevailing laws and regulations, public order, religion, or morality ${ }^{6}$ and the protection shall be granted for ten years commencing from the filing date; and the date of commencement of the protection period shall be recorded in the General Register of Industrial Designs and announced in the Official Gazette of Industrial Designs. ${ }^{7}$ Those entitled to receive the right to an industrial design shall be the Designer or those who receive the right from the Designer; and where the Designer comprises several persons jointly, the right to an industrial design shall be granted to them jointly, unless agreed otherwise. $^{8}$

2 Developing countries, which are member States of WTO, were given different periods of time to adapt their intellectual property systems before being obliged to apply the TRIPS Agreement until January 1, 2006. See also Carlos M. Correa, "Intellectual Property Rights, the WTO and Developing Countries, The TRIPS and Policy Options" 8 et seq. (London \& New York, Zed Book Ltd 2000) that the position of TRIPS to the WTO is as a minimum standard that should be fulfilled by every WTO member.

3 Art. 1 (2) of Industrial Design Law No.31 of 2000 stipulates that Designer(s) shall mean a person or several persons who produce an industrial design. See also Marshall Leaffer, "Understanding Copyright Law" 14 et seq. (New York, Matthew Bender \& Co., Inc., 1998), that IPR grants an exclusive right to inventor, creator or designer of their intellectual works.

4 Art. 5 para. (1) of Industrial Design Law No. 31 of 2000 stipulates that the protection of the right to Industrial Design shall be granted for 10 (ten) years commencing from the Filing Date.

5 See Art. 9 of Industrial Design Law No. 31 of 2000.

6 Ibid, Art. 4.

7 Ibid, Art. 5.

8 Ibid, Art. 6. See also Art. 7 para. (1) which stipulates that where an industrial design is created in an official relation to another party within the working environment, the Right holder to industrial design shall be the party for whom the industrial design is created, unless there is another agreement between both parties without detracting the right of the Designer if the use of the industrial design is expanded beyond the official relation. Art. 7 para. (2) stipulates that the provision as referred to in para. (1) shall also apply to any industrial design created by other parties on the basis of an order made in an official relation. 


\section{The Weak Aspects of the Industrial Design Law}

Since the enactment of Law No. 31 of 2000 regarding Industrial Design on December 20,2000, in practice several cases have occurred and been brought before the Commercial Court involving the cancellation of lawsuits with regard to issues of the lack of 'novelty' of an industrial design which have already been granted to other people. A lawsuit on the cancellation of the registration of an industrial design may be filed by any interested party to the Commercial Court on the grounds that the industrial design is not new ${ }^{9}$ or the rights to the industrial design granted are contrary to the prevailing laws and regulations, public order, religion, or morality. ${ }^{10}$

There are several weak aspects of the Industrial Design Law which in practice can create legal uncertainty and may potentially cause a barrier towards the effectiveness of the implementation of the Industrial Design Law, as follows:

1. The Substantial Aspect of the Industrial Design Law

Industrial design shall mean a creation in the shape, configuration, or the composition of lines or colours, or lines and colours, or the combination thereof in a three or two dimensional form which gives aesthetic impression and can be realized in a three or two dimensional pattern and be used to produce a product, goods, an industrial commodity or a handy craft. ${ }^{11}$

Article 25 para. (1) of the TRIPS Agreement stipulates that "Members shall provide for the protection of independently created industrial designs that are new or original. Members may provide that designs are not new or original if they do not significantly differ from known designs or combinations of known design features. Members may provide that such protection shall not extend to designs dictated essentially by technical or functional considerations." Article 25 basically determines that an industrial design is considered as new if it differs significantly from known designs or a combination of known design features.

The system of industrial design protection applied by the Industrial Design Law explicitly only requires that an industrial design should be "new"; no "originality" requirement is necessary. Article 2 of the Industrial Design Law stipulates that the right to industrial design shall be granted for an industrial design that is new; an industrial design shall be deemed new if on the filing date such industrial design is not the same as any previous disclosures. The previous disclosure shall be one which before, namely: a) the filing date; or b) the priority date, the application is filed with priority right has been announced or used in Indonesia or outside Indonesia.

The difference between one industrial design and another industrial design must be based on the aesthetic impression as stipulated in Article 1 para. (1) of Law No. 31 of 2000 concerning Industrial Design; that an industrial design creation is to give an aesthetic impression. Therefore, an industrial design is considered new, if it has a different aesthetic impression and if it differs significantly from known designs or combinations of known design

Art. 7 para. (3) stipulates where an industrial design is created under a work relationship or on the basis of an order, the party that has created the industrial design shall be deemed as the Designer and the Right holder to industrial design, unless otherwise agreed by both parties.

9 Ibid, Art. 2.

10 Ibid, Art. 4.

11 Ibid, Art. 1 para. (1). 
features. This provision is in compliance with Article 25 para. (1) of the TRIPS Agreement

The meaning of "novel" is when the industrial design application filed at the Directorate General of Intellectual Property, is "different" from the prior disclosure. "The novelty" of industrial design is an absolute requirement to obtain protection for the industrial design. Therefore, it will not be acceptable if the owner of the industrial design has made and used the industrial design before the application is made to the Directorate General of Intellectual Property.

In practice, several issues concerning the "novelty" of industrial design are as follows:

First, no search is made of the prior art to determine whether the substantive criterion of novelty is satisfied by the design for which registration is sought. As a consequence, many registered industrial designs are not new or have no criterion of novelty, particularly in areas where a range of products performing the same function are available on the market; therefore, it is considered as public domain.

Secondly, there is the question of entitlement to legal protection in respect of an industrial design where the certificate is given not to the true Rights holder as there is bad faith on the part of the applicant by having intentionally registered an industrial design that is not novel, already known to the public or has already been circulated in the same business sector.

The interpretation of a "different" industrial design, in practice, does not mean "significantly not the same". Therefore, when it is slightly different, it is considered as not the same, so that it can be considered as a new design. A design can be considered as the "same" if the two designs that are compared are totally one hundred percent the same. If there is just a slight difference, it can be considered as new. In other words, even though it is similar, it is considered to be not the same. With such an interpretation, the criterion of "novelty" that is regulated in the Industrial Design Law can potentially cause conflict due to the many products that have similarities; however, the Rights holder of the industrial design certificate will have difficulties to claim that other parties are infringing/violating his rights, since to be constituted a violation of an industrial design, the other party's design must be totally the "same".

\section{Aspect of Administrative Procedure and Substantive Examination} position

First, there will be no substantive examination, unless there is op-

The substantial and administrative procedure is one of the problems in the implementation of the Industrial Design Law. Where there is no objection against an application until the termination of the publication period, the Directorate General shall issue and grant a Certificate of Industrial Design, at the latest thirty days from the date of termination of the publication period..$^{12}$ No substantive examination means that every industrial design application must be granted and the applicant will receive an industrial design Certificate. The Certificate of industrial design shall be effective as of the filing date; however, the question of who is the rightful owner of the industrial design and whether the "novelty" of the industrial design still exists can still be challenged and

12 Ibid, Art. 29. 
questioned by another party through the Court proceedings.

The grant of industrial design rights without the substantive examination process, if there is no objection, can potentially cause legal uncertainty with regard to the "novelty" and the true Rights holder of a design. The industrial design examiner will only carry out substantive examination if there is an objection from another party against an application for industrial design. As a consequence, the holder of the industrial design certificate has performed a criminal action by reporting to the police those people who use, produce, and market or sell the design products on grounds of infringement of the industrial design as well as an action for legal damages based on civil action. This act is considered unfair as the holder of the industrial design certificate is not truly the Designer.

The weakness of this substance is the most fundamental weakness of the Industrial Design Law that in practice will potentially give a chance to an applicant, having bad faith, who intentionally registered an industrial design that is not new; then, the holder of the certificate of the industrial design will file a lawsuit against his/her business competitors on the grounds of infringement of industrial design.

Art. 12 stipulates that the party who first files an application shall be deemed as the Rights holder to an industrial design, unless proven otherwise. Further, Art. 38 stipulates that a lawsuit on the cancellation of the registration of an industrial design may be filed by any interested party to the Commercial Court on the grounds that the industrial design granted is not new (is the same as any previous disclosures) or the industrial design granted is contrary to the prevailing laws and regulations, public order, religion, or morality. The Decision of the Commercial Court on the cancellation of registration of the right to an industrial design shall be delivered to the Directorate General, at the latest fourteen days after the date of the decision. It is stipulated also in Art. 43 that the cancellation of registration of an industrial design shall nullify all legal consequences connected with the right to the industrial design and other rights derived from the industrial design.

\section{Second, the long application procedure and impracticality of it}

The right to an industrial design shall be granted on the basis of application $^{13}$, known as a constitutive system - no registration, no protection. Basically, according to Law No. 31 of 2000 concerning Industrial Design, Indonesia has adopted the procedure of semi-substantive examination, as there are two possibilities in the procedure for granting (industrial design) rights: First, without going through the substantive examination (novelty) if no party had an objection during the three months period of publication ${ }^{14}$, and secondly, through the substantive examination process (novelty) if there are other parties who filed objections against the application during the three month period of publication. ${ }^{15}$

Before applying for an industrial design registration, the applicant must prepare the completeness of the application. To be accepted at the counter of application and obtain the filing date, the application must fulfill the minimum requirements, namely:

13 Ibid, Art. 10.

14 Ibid, Art. 29 para. 1

15 Ibid, Art. 26 para. 5 
a. To fill in the application form

b. To submit a physical sample or drawing or photograph and a description of the industrial design being applied for registration; and

c. To pay the application fee as referred to in the prevailing law and regulation

In addition to the minimum requirements, there are other requirements that must be fulfilled, namely:

a. a special power of attorney, if the Application is filed through a proxy. ${ }^{16}$

b. a statement that the industrial design being applied for registration is owned by the applicant or owned by the designer. ${ }^{17}$

c. If the application is jointly filed by more than one applicant, such application shall be signed by one of them by attaching a written agreement from the other applicants. ${ }^{18}$

d. If the application is not filed by the Designer, such application shall be furnished with sufficient evidence that the applicant is entitled to the specific industrial design. ${ }^{19}$

If the requirements have been fulfilled by the applicant and received by the Directorate General of Intellectual Property, the Directorate General of Intellectual Property will examine the requirements of the application. The examination includes the formalities examination (administrative) towards the completeness of the application, ${ }^{20}$ and a physical examination covering the classification of the industrial design, the clarity and unity of the industrial design..$^{21}$ It will also be checked whether the application for industrial design is contrary to the prevailing laws and regulations, public order, religion, or morality.

After the process of examination, if the requirement is found incomplete (such as a deficiency in the application, unclear drawing, or the description of the industrial design does not match with the drawing, the Directorate General of Intellectual Property shall notify the applicant or his/her proxy concerning the deficiencies and they should be amended and completed within the three month time period. ${ }^{22}$ If within those three months, said requirements can not be fulfilled, the period can be extended for one month at the request of the applicant. ${ }^{23}$ The consequence of failing to meet the time period is the application will be regarded as having been withdrawn and all costs which have been paid to the Directorate General of Intellectual Property are non-refundable. ${ }^{24}$

An application which has fulfilled the requirements shall be announced by the Directorate General of Intellectual Property at the latest three months from the filing date. ${ }^{25}$ During the announcement, each party may submit a

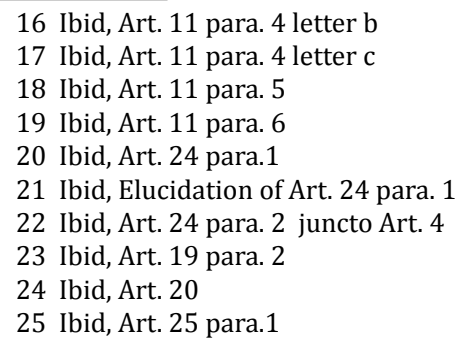


written objection covering substantial matters to the Directorate General of Intellectual Property by paying certain costs in accordance to the Governmental Regulation concerning the Non-Tax of State Revenue (NTSR).

If within the publication period any party files an objection against an application, the Directorate General of Intellectual Property will conduct a substantive examination of said application. ${ }^{26}$ The applicant is given an opportunity to submit a counter against the objection at the latest three months as of the date of sending notification by the Directorate General of Intellectual Property. ${ }^{27}$ The substantive examination will be conducted by the examiner at the latest six months commencing from the date of the termination of the publication period ${ }^{28}$ of which the objection and the counter that were previously submitted will be used as material for consideration in examining whether to register or to refuse the application. The Directorate General shall be obligated to produce a decision whether to register or to refuse the application at the latest six months from the termination date of the publication.

3. The administrative procedure is not yet in compliance with the international application of industrial design (the Hague Agreement - Geneva Act 1999)

The ratification of the agreement establishing the World Trade Organization and the Agreement on Trade Related Aspects of Intellectual Property Rights (the TRIPS Agreement) support the ratification of the Paris Convention for the Protection of Industrial Property by virtue of Presidential Decree No. 15 of 1997 and the participation of Indonesia in the Hague Agreement (London Act) concerning the International Deposit of Industrial Designs. However, Indonesia is not yet a member of the Geneva Act of The Hague Agreement and the Locarno Agreement. Although Indonesia is not a member of the Locarno Agreement, however, in practice, Indonesia uses the Locarno Classification as the main reference for examination of an application for industrial design to maintain the existing national classification system for industrial designs.

Although the registration procedure has been completely regulated, there are still several things that need to be perfected so that the registration procedure is more practical and better, such as the following:

a. The registration process needs to be re-arranged starting from the receipt of the application, substantive examination, the publication of an application, procedures for objections and the examination of a request for appeal, until the granting of a Certificate.

b. The procedure of the publication of an application should be conducted much faster after the substantive examination

4. There is no Industrial Design Appeal Commission

The Appeal Commission is a special independent agency that operates within the department in the field of intellectual property and it has the duty and authority to examine and decide on an appeal against the rejection of an

26 Ibid, Art. 26 para. 5

27 Ibid, Art. 26 para. 4

28 Ibid, Art. 26 para. 7 
intellectual property application. Due to the non-existence of an Industrial Design Appeal Commission, the designer does not have a significant opportunity to defend his/her designs. To avoid a backlog of intellectual property cases in the Commercial Court, it would be ideal to have an Industrial Design Appeal Commission that could examine and decide an appeal against the rejection of an industrial design in order to simplify the process, lower costs and quickly settle matters, compared to the Commercial Court.

5. The absence of some implementing regulations of the Industrial Design Law

The absence of several implementing regulations of the Industrial Design Law may have an impact on or will affect the administrative system and effectiveness of the enforcement of Industrial Design Law implementation. The only implementing regulation that has been issued after the promulgation of Industrial Design Law No. 31 of 2000 on December 20, 2000, is Governmental Regulation No. 1 of 2005 concerning the Implementation of Law No. 31 of 2000 concerning Industrial Design. There are still three Presidential Decrees, which up to now have not yet been issued, namely: Presidential Decree concerning the Requirements and Procedure of Granting Copies of the Certificate of Industrial Design; Presidential Decree concerning the Requirements and Procedure of the Recording of a Licensing Agreement; and Presidential Decree concerning the Requirements, Period and Procedure of the Payment of Fees.

\section{Conclusion}

It is a requirement of all industrial design laws that protection through registration shall be granted only to designs which are novel or, as it is sometimes expressed, original. The novelty of the design constitutes the fundamental reason for the grant of a reward to the originator through protection by registration of an industrial design. The legal protection of industrial designs serves the important function of protecting one of the distinctive elements by which manufacturers achieve market access. In so doing, by rewarding the creator for the effort which has produced the industrial design, legal protection serves as an incentive to the investment of resources in fostering the design element of production.

The rights which are accorded to the proprietor of a validly registered industrial design again emphasize the essential purpose of design law in promoting and protecting the design element of industrial production. Industrial design law accords to the proprietor the exclusive right to prevent the unauthorized exploitation of the design in industrial articles.

The question of the entitlement to legal protection in respect of an industrial design will remain the existing issue which will impact the law enforcement of Law No. 31 of 2000 concerning Industrial Design in Indonesia. Moreover, an application should be examined to ensure that it meets the criterion of novelty although the system that is applied is that there will be no substantive examination if there is no opposition filed. Therefore, it may potentially cause industrial design cases in terms of the proprietor of the industrial design. The controversies related to the weakness of the Industrial Design 
Law system should be minimized through the amendment of the Industrial Design Law to provide greater justice and legal certainty to the rightful owner of the industrial design (designer) as well as to those who receive the right from the Designer.

\section{References}

Republic of Indonesia, Law No. 31 of 2000 concerning Industrial Design

Presidential Decree No. 15 of 1997 concerning Ratification of the Paris Convention for the Protection of Industrial Property

Agreement on Trade Related Aspects of Intellectual Property Rights (TRIPs Agreement)

Governmental Regulation concerning the Non-Tax of State Revenue (NTSR)

Governmental Regulation No. 1 of 2005 concerning Implementation of Law No. 31 of 2000 concerning Industrial Design

Correa, Carlos M. "Intellectual Property Rights, the WTO and Developing Countries, The TRIPS and Policy Options" (London \& New York, Zed Book Ltd 2000)

Leaffer, Marshall "Understanding Copyright Law" (New York, Matthew Bender \& Co., Inc., 1998), 